\title{
Institutional Ownership Heterogeneity and Firm Performance: Evidence from Malaysia
}

\author{
Hamidon Katan ${ }^{1} \&$ Fauzias Mat Nor $^{2}$ \\ ${ }^{1}$ Malaysian Institute of Information Technology-Universiti Kuala Lumpur, Kuala Lumpur, Malaysia \\ ${ }^{2}$ Graduate School of Business, Universiti Kebangsaan Malaysia, Bangi Selangor, Malaysia \\ Correspondence: Hamidon Katan, Malaysian Institute of Information Technology, Universiti Kuala Lumpur, \\ 1016, Jalan Sultan Ismail, 50250 Kuala Lumpur, Malaysia. Tel: 60-321-754-316. E-mail: \\ hamidon@unikl.edu.my
}

Received: September 6, 2015

Accepted: October 20, 2015

Online Published: November 25, 2015

doi:10.5539/ijef.v7n12p176

URL: http://dx.doi.org/10.5539/ijef.v7n12p176

\begin{abstract}
The roles of institutional owners in alleviating agency problem and its effect on firms have been studied extensively in corporate finance. However, these researches have mixed results because most have treated institutional owners as a homogenous group. Drawing on previous research, this study differentiates institutional owners as transient or dedicated owners. These two groups of institutional owners differ significantly in terms of size of holdings, purposes, goals as well as monitoring efforts. The objective of this study is to determine how the institutional ownership structure i.e. transient or dedicated ownership affect firm performance within the context of agency theory. To determine whether treating the sample homogenously or heterogeneously has different effects on firm performance, this study also examine the effect of total ownership (whereby the sample is treated homogeneously) on firm performance. Using panel data that span from 2002 to 2006, several hypotheses are tested based on data of firms listed on Bursa Malaysia's Kuala Lumpur Composite Index (KLCI) using hierarchical regression analysis methodology. The empirical results indicate that total institutional ownership and dedicated ownership have no significant effect towards firm performance. Transient ownership, however, has statistically significant effect on firm performance. These results show that institutional ownership is heterogeneous with transient ownership structure monitor the management themselves. The establishment of the differing effect of institutional ownership due to the heterogeneous nature of ownership suggests that future research in this area must take into account the heterogeneity.
\end{abstract}

Keywords: institutional investors, corporate governance, board capital, dedicated ownership, transient ownership

\section{Introduction}

In corporate governance, there is always conflict of interest among participants in the corporate structure often referred to as agency problems (Eisenhardt, 1989). The main source of the conflict is that different participants have different goals and preferences. The second is that the participants have imperfect information of each other's actions, knowledge, and preferences. In order to get this relationship aligned requires a commitment to sustain interactions between a firm and its principal stakeholders such as institutional investors.

Institutional investors are shareholders with significant ownership positions, who have both the incentive to monitor executives and the influence to bring about changes they feel will be beneficial (Bethel et al., 1998). Thus, institutional investors have emerged as an important force in corporate monitoring (Black, 1990; Davis \& Thompson, 1994). The emergence of institutional investors is increasingly to be an important external control mechanism affecting governance worldwide. As major shareholders, institutional investors are expected to take the role of large shareholder and monitor management on behalf of the smaller shareholders and if necessary to incur expenses in intervening to correct mismanagement.

However, institutional investors is often treated as though institutional investors were a homogeneous group. The existing discussions on institutional investors have the tendency to treat them monolithically (Westphal \& Zajac, 1998), denying the fact that they are heterogeneous (Del Guercio \& Hawkins, 1999). Empirical studies that have tried to measure the effect of institutional ownership as a whole on corporate affairs have come away with mixed 
results. This is partly because of the inability of the research to distinguish the different types of institutional investors. Institutional investors differ greatly in size, purpose and goals. Institutional investor heterogeneity has been recognized and has been analyzed recently in the management literature (Ryan \& Schneider, 2003). Thus, there is a need for a fundamental rethink of the role of the different types of institutional investor in corporate governance and of their effect on the firm performance (Tricker, 1998).

The primary aim of the researcher in this study is to determine whether treating institutional investors into different heterogeneous types instead of a homogeneous group will give different results from Malaysia perspective. So far most studies on institutional investors have focused on the institutional investors as a homogeneous group. In this study the researcher has differentiated the institutional investors into two types (dedicated and transient) based on their trading pattern, the ownership value and the holding durations. The results of this study contribute significant implications for regulatory bodies preparing the best practices by treating differently for each of the institutional types.

This paper is structured as follows. First, the review of literatures on institutional investors such ownership, monitoring as well as their contribution towards firm performance is presented. This is followed by the hypotheses development. Next, the detail results of the study are presented and finally this paper is concluded with the discussion based on the results and suggestions on the future direction of the study are also offered.

\section{Literature Review}

Separation of ownership and management provides the opportunity for managers and agents to act in their own self-interest by maximizing their own wealth and power at the expense of the owners (Fama, 1980; Jensen \& Meckling, 1976). Agency theory is the most dominant theoretical framework in corporate governance research. Agency cost is the result when managers pursue their own interests to the detriment of the interests of shareholders (Fama \& Jensen, 1983). Therefore, by monitoring the management will reduce the agency costs inherent in the separation of ownership and control and, in this way, improve firm performance (Fama, 1980; Mizruchi, 1983; Zahra \& Pearce, 1989).

Institutional investors have the potential to influence management's activities through their ownership. However, there are differences between institutional investors in developing capital markets and institutional investors in other developed markets. These institutional differences include a weak market for corporate control (Lins, 2003), more concentrated stock ownership (Shleifer \& Vishny, 1997; Claessens et al., 2000), and significant government ownership in listed firms (Shleifer \& Vishny, 1997; Claessens et al., 2000; Lemmon \& Lins, 2003).

\subsection{Ownership Structure and Monitoring}

Theoretically, the presence of large shareholders should reduce agency costs and enhance firm performance (Jensen \& Meckling, 1976), since large shareholders have the incentive as well as the resources to monitor the firm's performance. Large shareholders tend to engage in closer monitoring activities, which reduce informational asymmetries between owners and managers as well as between the firm and external investors. The result is an enhanced monitoring structure and increased firm value, to the benefit of all shareholders.

There are two ways to explain the study on ownership, namely type of ownership and ownership concentration. Various individual, institution, Government, foreign and managerial ownership are the example of ownership type. Ownership concentration, on the other hand, is one of the ways that ownership could limit agency problem through large shareholdings (Shleifer \& Vishny, 1986, 1997; Noe, 2002). Cornet et al. (2003) in their study of S\&P 100 companies between 1993 and 2000 find positive and significant relationship between the firm's operating profit and percent of institutional investors ownership as well as with the number of institutional investors. McConnell and Servaes (1990) and Del Guercio and Hawkins (1999) also found institutional investors in the US appear to be more effective in monitoring firms' performance than individual investors. In Malaysia, concentration of shareholding through cross holding and the pyramid are very common (Nor, Fauzias-Mat \& Bany, 2005).

Agency problems caused by the separation of ownership and control may not be prevalent in countries where large shareholders dominate (Gillan \& Starks, 2003). However, not all studies show the positive relationship. Demsetz and Lehn (1985) found no significant correlation between ownership concentration and firm performance for 511 large US firms. Holderness and Sheehan (1988) also found no significant differences between accounting rates of return of paired majority-owned and diffusely held firms. Seifert et al. (2005) in another study found that the impact of institutional ownership and performance is clearly mixed when they examined the effects of institutional ownership on performance using samples of firms from four countries (US, UK, German and Japan). The influence of institutions ownership and firm performance is not consistent across 
the four countries. This may suggest that institutional impact on firm performance depends on the differences in the institutional and regulatory environments among the countries.

In the Malaysian context, Claessen et al. (2002) in their study of 171 Malaysian firms listed in Bursa Malaysia found a positive and significant relationship between ownership concentration and corporate performance. They also noted that ownership structure plays an important role in structuring the corporate governance mechanism, especially in countries with weaker governance. Samad (2004) in her study of 731 public listed companies in KLSE concluded that ownership concentration has also been found to lead better firm performance. She also argued that ownership concentration is the most important factor in shaping the corporate governance system in Malaysia.

\subsection{Reviews on Institutional Investor}

The advent of institutional investors as equity owners as external control mechanism is affecting governance worldwide. Institutional investors influence management's activities directly through their ownership and indirectly by trading their shares. The effectiveness and credibility of the entire corporate governance system to a large extent depend on institutional investors that can make informed use of their shareholder rights and effectively exercise their ownership functions in companies in which they invest.

Institutional investors are different in ownership size, purpose and objectives. They might be a significant shareholder with significant stake in the target company in order to be able to have access to management and to receive privileged information. They are also able to influence the management performance. On the other hand, they could be those mutual funds with a short-term orientation with fund managers being rewarded by the performance of the fund periodically.

Most of the previous studies on institutional investors have rested on the assumption that all institutional investors have the same investment goals and will therefore behave in the same way with regard to corporate outcomes. However, some researchers have cast doubt on both of these assumptions (Brickley et al., 1988; Griffin \& Mahon, 1997). Bushee (1998) then classifies institutions into transient, dedicated and quasi-indexer type. This categorization is based on their past investment patterns in the areas of portfolio turnover, diversification, and momentum trading. Transient institution is characterized by high levels of portfolio turnover and diversification, short-term focus and has little interest in long-term capital appreciation or dividends (Porter, 1992). Dedicated institution is described as institution holding large stakes in firms and but with low portfolio turnover. The large, stable ownership positions of dedicated institutions create incentives for them to secure better access to private information of its portfolio companies. This inside information will enable them to effectively monitor managers and it might increase firm performance (Porter, 1992). Quasi-indexer institution is institution with low portfolio turnover but highly diversified holdings. Quasi-indexer institutions adopt a passive, buy-and-hold strategy of investing (Porter, 1992). Because of this passive and fragmented investment style gives them little incentives to monitor managers.

\subsection{Institutional Investor and Performance}

Two theoretical perspectives that highlight the heterogeneous of institutional investors and drive research on the effects of institutional investment are the efficiency abatement hypothesis (Hill et al., 1988; Jacobs, 1991) and the efficiency augmentation hypothesis (Brancato, 1997; Chaganti \& Damanpour, 1991; Hansen \& Hill, 1991). The efficiency abatement view posits a negative relationship between institutional investment and firm value because investors are passive, collusive or myopic. The efficiency augmentation viewpoint, which posits a positive relationship between institutional investment and firm performance, rests on two arguments: superior investor hypothesis and active investor hypothesis.

Under the active monitoring hypothesis, it is believed that, because of the magnitude of wealth invested, institutions are likely to actively manage their investment. Academic researchers have generally documented evidence consistent with the active monitoring hypothesis such as improvement in stock price performance and firm profitability (Brous \& Kini, 1994). Institutional investors also have strong interest in the strategies, activities, and other stakeholders of those firms (Gilson \& Kraakman, 1991; Holderness \& Sheehan, 1988; Pound, 1992; Smith, 1996) and are perceived as having relevant information regarding the firms in which they invest.

Researches examining the relationship between institutional ownership and firm performance have generally produced mixed results. Researchers such as Brickley et al. (1988), Bushee (1998), Wahal and McConnell (2000), Hartzell and Starks (2003), Almazan et al. (2005), and Borokhovich et al. (2006) have shown that certain types of institutional investors exert influence on anti-takeover amendments, R\&D investment decisions, and 
CEO compensation. Among the researches supporting the existence of this relationship comes from Baysinger et al. (1991), McConnell and Servaes (1990) and Hartzell and Starks (2003). However, Chaganti and Damanpour (1991) and Jennings (2005) find little empirical support for the hypothesis that institutions undertake monitoring to improve a firm's quality and valuation. Some researches even find no evidence of a monitoring role by institutional investors (Renneboog, 2000; Seifert et al., 2005).

\section{Hypotheses Development}

Ownership stakes held by institutions formed a sufficient basis of power. Over the past decade, institutional investors have increasingly resorted to activism by confronting poorly managed firms with public criticism of their policies, initiation of shareholder proposals, and negotiations with managers (Davis \& Thompson, 1994). Institutional investors are usually major shareholders with the capabilities of professional investors and therefore they have the capability to monitor the managers of their portfolio companies. Previous studies provide confirmation that institutional investor activism provides external monitoring mechanisms (Hansen \& Hill, 1991; Zahra, 1996) through activities such as direct negotiations, public announcements, and shareholder proposals (David et al., 2001; Wahal, 1996).

Several recent studies have recognized the heterogeneity of institutional investors (e.g. Almazan et al., 2005; Bushee, 1998; Chen et al., 2007). They acknowledged that institutional varies significantly in terms of their sizes, purposes and goals. There are relationship investors who are long-term investors, take a significant stake in the firm and able to influence the management and able to received privileged information because of their sizes. On the other hand, there are mutual funds that are focusing on the short-term results. In between these two, lie the rest of the institutional investors. Hence, if the institutional ownership is treated as homogeneous, total institutional ownership shall have no significant effect towards firm performance. Therefore, the first hypothesis is;

\section{Hypothesis 1: Total institutional ownership is insignificantly related to firm performance.}

Many studies have recognized that the distinctiveness of different owners has important implications for firms because different owners can have different objectives (Bushee, 1998; Thomsen \& Pedersen, 2000). The dedicated investors are expected to take a significant stake in the target company so that they are able to have access to the management, to obtain privileged information, to influence and to improve management performance. This view suggests that institutional investors play an important role in reducing agency problems by taking a greater interest in the long-term value of their portfolio firms (Bushee, 1998).

Dedicated investors have to actively monitor the management of the portfolio firm because they stand to lose more money than smaller investors (Bushee, 1998; Tihanyi et al., 2003). Their exit option will become more expensive as the size of their shareholding increases because large block sales generally require steep discounts (Pound, 1992; Black \& Coffee, 1994). Therefore, dedicated institutional investors may directly affect firm performance. Hence, it is predicted that dedicated type of institutional ownership type of fund has positive effect on the performance of the firm. Thus, a hypothesis is developed that dedicated institutional ownership may also have positive direct effects on their portfolio firms' performance (Tihanyi et al., 2003; Wahal, 1996).

\section{Hypothesis 2: Dedicated institutional ownership is significant and positively related to firm performance.}

Transient type of institutional investors prefers quick value gains and therefore they are not too keen to a long-term holding (Bushee, 1998). However, transient institutional investors can be considerably affected if the market reacts unfavorably to them. They may take longer to liquidate a large position in a firm (David et al., 2001). Past studies have shown that transient institutional investors are not interested to play an active role in firms' long-term investment decisions. It is because long-term commitments require long payback periods and it is against their policy to seek short-term stock gains (Bushee, 1998; Zahra, 1996). Zahra (1996) suggests that transient investors prefer to sell their holdings rather than attempting to change the management of their portfolio companies.

According to Starks, mutual fund's primary objective is a high current return because of their own reward systems, which emphasize quarterly performance (Starks, 1987). She reported that mutual fund managers receive a percentage of the value of assets and a bonus or penalty based on how their funds perform relative to an index calculated quarterly. This pressure on mutual funds for short-term profitability, coupled with the potential difficulty of selling large blocks of stock without a loss, may result in a preference for strategies and projects with a high probability of a short-term payoff. Thus, it is expected that mutual fund managers to emphasize on short-term performance in most decisions and to press firm management to adopt this orientation. Studies indicate that mutual fund managers tend to hold a given firm's stock for less time than pension fund managers 
(Gilson and Kraakman, 1991) and that they may adopt a trader orientation and increase or decrease the riskiness of their portfolios by move in and move out of stocks in an attempt to maximize their expected compensation (Brown et al., 1996). Based on both arguments explained above, this hypothesis is put forward;

\section{Hypothesis 3: Transient institutional ownership is significant and negatively related to firm performance.}

\section{Data and Research Methods}

Since institutional investors tend to target large firm (David et al., 2001), this study select all firms listed on Kuala Lumpur Composite Index (KLCI) of Bursa Malaysia. KLCI consists of 100 blue-chip firms in Bursa Malaysia which represent the whole of Bursa Malaysia listed firms and being used as the Bursa Malaysia index tracker. The institutional ownership data are collected manually from firm's annual report downloaded from Bursa Malaysia website. However, not all 100 companies survived during the period of the study. There were five (5) companies did not survive during the whole of the period of study and had to be removed. From the 95 companies left, I have to remove another five (5) companies from the sample because of unavailability of data in some of the variables. The corresponding financial data is collected from Datastream Database. The data collected is from year 2002 until 2006.

The institutional ownership is then divided according to their objectives and trading styles based on Bushee (1998) grouping, except quasi-indexer. I followed the framework similar to studies by Eakins (1995) and Tihanyi et al. (2003). The two main types of institutional investors defined in my study are dedicated ownership and transient ownership. The first type, dedicated ownership consists of Pension funds as well as Government funds namely Khazanah, Employee Provident Fund (EPF), Lembaga Tabung Haji (LTH) and Lembaga Tabung Angkatan Tentera (LTAT). The Malaysian Government has acknowledged that these organisations are Government proxies in making investments on behalf of the government. These GLIC investment patterns are characterized by the dedicated type of institutional investor which makes large investment on selected firms as well as long-term investment.

The second type of institutional investor namely transient ownership represents the characteristics of the high level of portfolio turnover and a high level of portfolio diversification. One of the major types of transient ownership is mutual fund. Mutual funds' performance is based on short-term investment styles in order to show good income statement in every quarter. These types of funds is put into this type if the company name consists the word 'Fund' or 'Mutual' or 'Investment'. The main mutual funds found in the list of Top 30 Shareholding in the firm's annual report are Permodalan Nasional Berhad (PNB), Amanah Saham Nasional (ASN) and Amanah Saham Wawasan (ASW).

\subsection{Research Model}

Model 1: Tobin- $_{i t}=a_{0}+a_{1}$ FSIZE $_{i t}+a_{2}$ FPROFIT $_{i t}+a_{3} F L E V E R_{i t}+\varepsilon_{i t}$

Model 2: Tobin- $Q_{i t}=a_{0}+a_{1} O W N_{i t}+a_{2} F_{S I Z E_{i t}}+a_{3} F P R O F I T_{i t}+a_{4} F L E V E R_{i t}+\varepsilon_{i t}$

Model 3: Tobin- $Q_{i t}=a_{0}+a_{1}$ DOWN $_{i t}+a_{2}$ FSIZE $_{i t}+a_{3} F P R O F I T_{i t}+a_{4} F L E V E R_{i t}+\varepsilon_{i t}$

Model 4: Tobin- $Q_{i t}=a_{0}+a_{1}$ TOWN $_{i t}+a_{2}$ FSIZE $_{i t}+a_{3} F P R O F I T_{i t}+a_{4} F L E V E R_{i t}+\varepsilon_{i t}$

Model 5: Tobin- $Q_{i t}=a_{0}+a_{l} D O W N_{i t}+a_{2}$ TOWN $_{i t}+a_{3}$ FSIZE $_{i t}+a_{4} F_{P R O F I T_{i t}}+a_{5} F L E V E R_{i t}+\varepsilon_{i t}$

\subsection{Operationalization of Variables}

The measurement of firm performance utilized as the dependent variable is Tobin-Q. Tobin-Q is defined as the ratio of the market value to the replacement value of the firm (Tobin, 1969). Another way to compute Tobin-Q is as the ratio sum of market capitalization and total debts to book value of total assets. As a market-based performance measures, Tobin- $\mathrm{Q}$ is argued to be superior compared to accounting-based measures such as ROA and ROE since market-based measures are the reflection of the sentiments and the confidence of investors towards listed firms. Market-based measures are typically viewed as somewhat more robust given that they are not subject to direct manipulation by management. There are many other researches which have used this proxy (Mehran, 1995; Demsetz \& Lehn, 1983; Chung \& Pruitt, 1994, Holderness et al., 1999).

To get the total ownership by each of the two types, the ownership of each institutional investor is measured by adding the percentage of ownership for each group, provided that the ownership is above 5\%. Demsetz and Lehn (1985) argue that ownership holding of $0.5 \%$ is sufficient to influence corporate outcomes. Their studies are based on big and developed market. However, because Malaysian firm's shareholdings are relatively small compared to other developed western countries under study by them, this study choose to use $5 \%$ as the minimum shareholding of the institutional investors to be included in the calculation of institutional ownership. This $5 \%$ imposition is also to remove institutional investors with marginal equity positions and included only 
funds with ownership adequate to promote interest and activism (Demsetz and Lehn, 1985; Johnson and Greening, 1999).

\subsection{Control Variables}

Firm Size: Numerous studies have argued that firm size is a positively related to the relation between governance structure and performance. Ang et al. (2000) and Singh and Davidson (2003) suggest that there are economies of scale for larger and institutional investors' decisions to hold a firm's common stocks are positively related to firm size. Company performance may be a function of size (larger firms are more profitable than smaller firms are) and may bias the result. The natural log of total assets is used as proxy for size.

Firm Profitability: Firm profitability is measured by return on assets (ROA) and has been shown to be a determinant of firm performance. Previous research has tended to find a positive association between profitability and firm performance (Klein, 1998).

Firm Leverage: Leverage reduces agency costs by reducing the cash flow that is available for discretionary use by the management (Jensen, 1986). Empirical evidence supports the effectiveness of debt as a control device (Ang et al., 2000; Berger et al., 1997). Leverage which measures the extent to which total asset have been financed with debt is based on percentage of total debt to total assets. In this study, the natural log of leverage is used.

\subsection{Data Diagnostics and Data Analysis}

The statistical methods used to provide the answers to the hypotheses developed in the previous chapter is hierarchical regression analysis, which is used for the estimation of all models in order to compare successive regression models and to determine the significance that each one has above and beyond the others. It is a more advanced form of simple linear regression and multiple linear regressions. Each model (hierarchy) can be compared using functions such as to ascertain the overall variance explained $\left(R^{2}\right)$ and statistical significance ( $F$-test) of each individual model, as well as the significance of each predictor to each model ( $t$-test). The coefficient of determination $\left(R^{2}\right)$ provides a measure of how well future outcomes are likely to be predicted by the model. The data is arranged in panel data type. For the econometric treatment of the sample data, the methods employed are Durbin-Watson Statistics and Auto-regressive of the first order. Durbin-Watson statistics is a test for first-order serial correlation and it measures the linear association between adjacent residuals from a regression model. Auto-regressive (AR) method is a common methods to account for serial correlation.

\section{Results Analysis}

Table 1. Descriptive statistics summary of the overall sample data

\begin{tabular}{lcrrrrrrr}
\hline \multicolumn{1}{c}{ Variables } & N & \multicolumn{1}{c}{ Min } & \multicolumn{1}{c}{ Max } & \multicolumn{1}{c}{ Mean } & Std Dev & \multicolumn{1}{c}{ Skewness } & \multicolumn{1}{c}{ Kurtosis } \\
\hline Tobin-Q & 450 & 0.192 & 11.642 & 3.002 & 1.978 & 1.137 & 2.087 \\
Dedicated Ownership (\%) & 450 & 0.000 & 74.510 & 8.434 & 15.228 & 2.726 & 7.177 \\
Transient Ownership (\%) & 450 & 0.000 & 73.820 & 6.233 & 16.204 & 2.808 & 6.657 \\
Total Ownership (\%) & 450 & 0.000 & 80.940 & 14.918 & 21.888 & 1.626 & 1.304 \\
Firm Size & 450 & 8.057 & 15.250 & 11.844 & 1.419 & 0.203 & -0.259 \\
ROA & 450 & -30.060 & 43.092 & 4.326 & 7.390 & 0.573 & 8.626 \\
Leverage & 450 & -1.644 & 3.430 & 1.622 & 0.746 & -0.728 & 2.214 \\
\hline
\end{tabular}

Descriptive Statistics: The descriptive statistics analysis were done on all 450 firm-years sample based on yearly descriptive and the overall for the five year period from 2002 until 2006. The descriptive statistics are shown in Table 1.

The correlation analysis: Table 2 shows the correlation table of the variables used in this study. Tobin-Q with transient institutional ownership and institutional total ownership is of negative values and statistically significant. On the other hand, dedicated institutional ownership is positively correlated with Tobin-Q but not significant. Independent director is not significantly correlated with Tobin-Q with positive sign. Total directorate however is significantly correlated with Tobin Q with positive sign. Dedicated institutional ownership is positively and significantly correlated with total institutional ownership. Another ownership variable, transient institutional ownership is also highly correlated with total institutional ownership. As for multicollinearity, it can be seen from Table 2 that the VIF for the entire variables understudy do not have multicollinearity issues as all the VIF figures are less than 10, a number indicating multicollinearity. 
Table 2. The correlation table of the research variables

\begin{tabular}{|c|c|c|c|c|c|c|c|}
\hline Variables & 1 & 2 & 3 & 4 & 5 & 6 & VIF \\
\hline Tobin-Q & 1 & & & & & & \\
\hline Dedicated & 0.048 & 1 & & & & & 1.282 \\
\hline Ownership & $(0.311)$ & & & & & & \\
\hline Transient & $-0.154 * * *$ & -0.053 & 1 & & & & 1.157 \\
\hline Ownership & $(0.001)$ & $(0.258)$ & & & & & \\
\hline \multirow[t]{2}{*}{ Total Ownership } & $-0.081 *$ & $0.655^{* * *} *$ & $0.704 * * *$ & 1 & & & 1.347 \\
\hline & $(0.084)$ & $(0.000)$ & $(0.000)$ & & & & \\
\hline \multirow[t]{2}{*}{ Firm Size } & $0.089 *$ & $0.290 * * *$ & $0.110^{* *}$ & $0.284 * * *$ & 1 & & 1.413 \\
\hline & $(0.059)$ & $(0.000)$ & $(0.020)$ & $(0.000)$ & & & \\
\hline \multirow[t]{2}{*}{ ROA } & $0.158 * * *$ & -0.001 & 0.003 & -0.003 & $0.357 * * *$ & 1 & 1.252 \\
\hline & $(0.001)$ & $(0.982)$ & $(0.950)$ & $(0.943)$ & $(0.000)$ & & \\
\hline \multirow[t]{2}{*}{ Leverage } & $0.129 * * *$ & -0.028 & 0.004 & -0.002 & $0.131 * * *$ & $-0.156^{* * *}$ & 1.107 \\
\hline & $(0.006)$ & $(0.553)$ & $(0.934)$ & $(0.972)$ & $(0.005)$ & $(0.001)$ & \\
\hline
\end{tabular}

Note. $* * *, * * *$ indicates significance at a $0.01,0.05$ and 0.10 level respectively.

The hypotheses testing: There are three main areas in this hypotheses testing. First is the effect of control variables towards firm performance, which is Tobin-Q. Since hierarchical regression analysis is employed in this hypotheses testing, the first step is to analyze the effect of control variables towards Tobin-Q. Second is to test the direct effect of institutional ownership towards Tobin-Q. The hypotheses testing are based on the multiple regression analysis based on panel data. White Correction method is able to fix the standard deviation and the $p$-value, making the test results more accurate compared to no adjustment to the sample data. For the statistical analysis using panel data, options of Cross-section Weights and White Cross-section are used.

The effects of control variables- Table 3 shows that all three control variables is significantly related with Tobin-Q. Firm size (FSIZE) and leverage (LEVERAGE) are positively significant $(\beta=0.203, p<0.01$ and $\beta=$ $1.751, p<0.01$ respectively) and Return on Asset (ROA) is negatively related toward Tobin-Q $(\beta=-0.006, \quad p<$ 0.01). The positive coefficient for firm size does not support the findings of Weir et al. (2002), suggesting that the Malaysian market perceives bigger firms as better performers compared to smaller firms.

The result also shows that the positive and significant correlation coefficient for the control variable leverage differs from the result of Dowen (1995) and Weir et al. (2002). This result implies that the Malaysian market perceives leverage as an effective mechanism to control management and improve performance, as suggested by Jensen (1986) and Stulz (1990). On the other hand, ROA is negative and statistically significant in contributing towards firm performance. The result shows that ROA is inversely related to firm performance represented by Tobin-Q.

Hypothesis 1 is to test whether the relationship between total institutional ownership and firm performance is insignificant. As can be seen from Model 2 in Table 3, the relationship between total institutional ownership and Tobin-Q is positive but not statistically significant $(\beta=0.001, p>0.10)$. The result does support Hypothesis 1 , which predicts that total institutional ownership is insignificantly related to firm performance. The change in the amount explained variance from Model 1 is negative and statistically not significant.

Model 3 and Model 4 in Table 3 were constructed to test Hypothesis 2 and Hypothesis 3 respectively, which predict that if institutional ownership is segregated based on the characteristics of each institutional ownership, the model will better explained firm performance. The institutional investors is then divided into two types (dedicated and transient institutional investors) based on their characteristics (Bushee, 1998). The result presented in Model 3 does not support Hypothesis 2. It is expected that dedicated institutional investors because of their large stakes, long-term commitment as well as low portfolio turnover, should contribute significantly towards firm performance. However, the result reveals that even though the coefficient for dedicated institutional ownership is positive but it is not significant. The change in the amount explained variance from Model 1 is negative and statistically not significant.

Hypothesis 3 suggests that transient institutional ownership which is characterized by its high level of portfolio turnover and diversification and very short-term focus is not expected to contribute significantly and even expected to contribute negatively towards firm performance. The result however reveals a significant positive relation $(\beta=0.004, p<0.01)$ between transient institutional ownership and firm performance as shown in Model 
4 in Table 3. The result does not support Hypothesis 3. The result suggests that the higher transient institutional ownership, the higher firm performance.

Table 3. Direct effect of independent variables towards Tobin-Q

\begin{tabular}{lccccc}
\hline Variables & Model 1 & Model 2 & Model 3 & Model 4 & Model 5 \\
\hline Intercept & $-3.463^{* * *}$ & $-3.670^{* * *}$ & $-3.483^{* * *}$ & $-3.734^{* * *}$ & $-3.797 * * *$ \\
TOwn & & 0.001 & & & \\
Ded & & 0.001 & & 0.001 \\
Tran & & & $0.219^{* * *}$ & $0.217^{* * *}$ & $0.006^{* * *}$ \\
Fsize & $0.203^{* * *}$ & $0.221^{* * *}$ & $-0.005^{* * *}$ & $-0.007 * * *$ & $0.236^{* * *}$ \\
ROA & $-0.006^{* * *}$ & $-0.005^{* * *}$ & $1.723^{* * *}$ & $1.766^{* * *}$ & $-0.005^{* * *}$ \\
Leverage & $1.751^{* * *}$ & $1.744^{* * *}$ & $\mathbf{0 . 9 8 0}$ & $\mathbf{0 . 9 8 6}$ & $1.734^{* * *}$ \\
$\boldsymbol{R}^{2}$ & $\mathbf{0 . 9 8 6}$ & $\mathbf{0 . 9 8 2}$ & 0.980 & 0.986 & 0.980 \\
Adjusted $\boldsymbol{R}^{2}$ & 0.986 & 0.982 & 3441.607 & 4969.843 & 2906.877 \\
F-statistics & 6251.496 & 3834.343 & -0.006 & 0 & -0.006 \\
$\Delta \boldsymbol{R}^{2}$ & - & -0.004 & 0.037 & $6.853^{* * *}$ & $9.826^{* * *}$ \\
$\boldsymbol{F}$ for $\Delta \boldsymbol{R}^{2}$ & - & 1.003 & 2.190 & 2.175 & $2 . .189$ \\
Durbin-Watson & 2.172 & 2.183 & & & \\
\hline
\end{tabular}

Note. $* * * * * *$ indicates significance at a $0.01,0.05$ and 0.10 level respectively.

Model 5 in Table 3 shows the full model consist both dedicated and transient institutional ownership. The result reconfirms the earlier finding that transient institutional ownership explain better firm performance compared to dedicated institutional ownership, after controlling for firm size, ROA and leverage.

\section{Discussion and Conclusion}

This research showed that total overall ownership does not explain firm performance. The results of this study support the contention that it is necessary to consider different types of institutional investors to examine their differing impacts on firm performance. This finding is consistent with those reported by previous studies (e.g. Ryan \& Schneider, 2003; Westphal \& Zajac, 1998). Various researches extend those findings by suggesting that total ownership should be broken into various types of ownership based on their transaction pattern, holding period, size of the ownership as well as their monitoring efforts (Brickley et al., 1988; Bushee, 1998). As institutional investors become increasingly powerful in the corporate arena, it will become more and more critical for both researchers and practitioners to understand the heterogeneity of this enormous investor class.

Based on agency theory, dedicated institutional ownership, because of their size and long-term holding, is expected to monitor firms closely to optimize firm performance. However, it is not the case in this study. The result for dedicated institutional investors is unexpected since previous studies have provided evidence on the monitoring role of dedicated investors (Abdul Rahman \& Mohamed Ali, 2006; Abdul Jalil \& Abdul Rahman, 2010). There may be a few possible explanations regarding this finding. One of the possible explanation is that most Asian countries is characterizes by greater ownership concentration by individuals, families and government (La Porta et al., 1999). This is very much different from the US, which stresses on the dispersion of ownership. The other explanation is that Malaysia's economy is still in the developing stage and the Government feels that it is their social obligation to control the country's critical assets such as oil and gas, plantation, infrastructure and big manufacturing companies. The Government controls these firms through Government-linked Investment Companies (GLIC), which represents Government ownership.

The transient ownership, on the other hand, is not expected to monitor the management because of its short-term holding or high portfolio turnover and very much diversified to spread the risks (Porter, 1992). The short-term focus of the transient ownership makes them to sell of their holdings out of a firm with disappointing performance. However, the result of this study does not support this view. The result shows that transient ownership is positively related towards firm performance and this relationship is significant. A possible explanation for this result to happen maybe because in Malaysia, the total amount of mutual funds ownership is significant especially for KLCI listed companies. The maximum transient ownership is almost equivalent with the dedicated ownership as well as total ownership as shown in Table 1. The present findings add value to scholars' knowledge of corporate governance, indicating that different types of institutional investors do influence firm performance differently. The present study suggests that different types of institutional investors 
are heterogeneous in their preferences for firm performance.

Separate institutional owners may champion different firm strategies and thereby influence the firm performance. Understanding the heterogeneous preferences of institutional investors will become increasingly important. Better information on types of institutional investor's preferences may help the individual investors to optimize their investments. Firms, on the other hand also need to attract the right type of institutional investors in order to maximize the firm performance.

The results of this study may also have an important implication for practices. The results of this research provide the much needed input for the respective regulatory bodies preparing the best practices. Various best practice codes are imposed to improve a firm's overall governance standard. This study sheds light on the relative importance of various corporate governance practices; hence, it provides useful information to the regulatory authorities to design best practice codes tailored to both the Malaysian institutional background and the current level of capital market development in Malaysia.

\subsection{Research Limitations}

Even though many aspects of this study have been thought through properly, this study is not without limitations. First and most importantly, this study cannot separate the specific resources of the independent directors bring to boards (i.e., information, contacts, preferential access, influence, or legitimacy), nor can the study isolate the effects of their human or relational capital. Second, the sample selection is not totally random. The sample for this study is the 100 firms listed in the Kuala Lumpur Composite Index (KLCI) from the year 2002 until 2006. It is therefore necessary to interpret the results cautiously and the need to understand the framework and the objectives of this study. The generalization of this finding also needs to be done cautiously.

\subsection{Suggestion for Future Research}

Although there are valuable contributions and promising directions as discussed above, there are questions and issues that were unable to be pursued, given the scope of this research. First, this study only covers KLCI firms which are considered blue chip firms listed in Bursa Malaysia. In the Malaysian stock context, the Government takes the initiatives to hold and maintain substantial percentage of the shares in these firms through its investment arms, the GLICs. Therefore, the ownership data might be skewed towards concentrated block-holder ownership by the GLICs. By extending the data outside of KLCI such as the Main Board, there might be more variety of institutional investors as the shareholders and this may provide a more detail and accurate reflection of the effects of institutional ownership heterogeneity and firm performance relationship. Second, this study is Malaysian-centric view of the institutional ownership-firm performance and may not be generalizable to other countries. Thus, these findings need replication in firms with different country home bases; research designs reflecting the differences in corporate governance approaches across countries are especially important (e.g. Norburn et al., 2000).

\section{References}

Abdul Jalil, A., \& Abdul Rahman, R. (2010). Institutional Investors and Earnings Management: Malaysian Evidence. Journal of Financial Reporting and Accounting, 8(2), 110-127. http://dx.doi.org/10.1108/19852511011088370

Abdul Rahman, R., \& Mohamed Ali, F. H. (2006). Board, Audit Committee, Culture and Earnings Management: $\begin{array}{lllll}\text { Malaysian Evidence. Managerial Auditing Journal, 21(7), } & \text { 783-804. }\end{array}$ http://dx.doi.org/10.1108/02686900610680549

Almazan, A, Hartzell, J. C., \& Starks, L. T. (2005). Active Institutional Shareholders and Costs of Monitoring: Evidence from Executive Compensation. Financial Management, 34(4). http://dx.doi.org/10.1111/j.1755-053X.2005.tb00116.x

Ang, J., Cole, R., \& Lin, J. (2000). Agency costs and ownership structure. Journal of Finance, 55, 81-106. http://dx.doi.org/10.1111/0022-1082.00201

Baysinger, B. D., Kosnik, R. D., \& Turk, T. A. (1991). Effects of Board and Ownership Structure on Corporate R\&D Strategy. Academy of Management Journal, 34, 205-214. http://dx.doi.org/10.2307/256308

Berger, G., Eli, O., \& Yermack, D. L. (1997). Managerial entrench men and capital structure decisions. Journal of Finance, 52, 1411-1438. http://dx.doi.org/10.1111/j.1540-6261

Bethel, J., Liebeskind, J., Porter, J., \& Opler, T. (1998). Block Share Purchases and Corporate Performance. Journal of Finance, 53, 605-634. http://dx.doi.org/10.1111/0022-1082.244195 
Black, B. S. (1990). Shareholder passivity reexamined. Michigan Law Review, 89(520).

Black, B. S., \& Cofee, J. C. (1994). Hail Britannia? Institutional investor behaviour model under limited regulation. Michigan Law Review, 92, 1997-2087. http://dx.doi.org/10.2307/1289659

Blair, M. M. (1995). Rethinking assumptions behind corporate governance. Challenge, 38(6), 12-17.

Borokhovich, K. A., Brunarski, K. R., Donahue, M. S., \& Harman, Y. S. (2006). The Importance of Board Quality in the Event of a CEO Death. Financial Review, 41(3), 337-355. http://dx.doi.org/10.1111/j.1540-6288.1969.tb01741.x-i1

Brancato, C. K. (1997). Institutional Investors and Corporate Governance. Chicago, IL: Irwin Professional Publishing.

Brancato, C. K. (1997). Institutional investors and corporate governance: Best practices for increasing corporate value. Chicago: Richard D. Irwin, Inc.

Brickley, J., Lease, R., \& Smith, C. (1988). Ownership structure and voting on antitakeover amendments. Journal of Financial Economics, 20, 267-292. http://dx.doi.org/10.1016/0304-405X(88)90047-5

Brous, P., \& Kini, O. (1994). The Valuation Effects of Equity Issues and the Level of Institutional Ownership, Evidence from Analysts' Earnings Forecasts. Financial Management, 23(1), 33-46. http://dx.doi.org/10.2307/3666054

Brown, K. C., Harlow, W. V., \& Starks, L. T. (1996). Of tournaments and temptations: An analysis of managerial incentives in the mutual fund industry. Journal of Finance, 51(1), 85-110. http://dx.doi.org/10.1111/j.1540-6261.1996.tb05203.

Bushee, B. J. (1998). The influence of institutional investors on myopic R\&D investment behavior. Accounting Review, 73, 305-333.

Chaganti, R., \& Damanpour, F. (1991). Institutional ownership, capital structure, and firm performance. Strategic Management Joumal, 12, 479-491. http://dx.doi.org/10.1002/smj.4250120702

Chen, X., Hartford, J., \& Li, K. (2007). Monitoring: Which institutions matter? Journal of Financial Economics, 86, 279-305. http://dx.doi.org/10.1016/j.jfineco.2006.09.005

Chung, K., \& Pruitt, S. W. (1994). A simple approximation of Tobin's Q. Financial Management, 23(3), 70-74. http://dx.doi.org/10.1016/j.jfineco.2006.09.005

Claessens, S., Djannklov, S., \& Lang, L. H. P. (2000). The separation of ownership and control in east Asian $\begin{array}{lllll}\text { corporations. Journal of Financial } & \text { Economics, } & \text { 58, } & \text { 8112. }\end{array}$ http://dx.doi.org/10.1016/S0304-405X(00)00067-2

Claessens, S., \& Fan, P. H. J. (2002). Corporate governance in Asia: A Survey. International Review of Finance, 3(2), 71-103. http://dx.doi.org/10.1111/1468-2443.00034

Cornett, M. M., Marcus, A. J., Saunders, A., \& Teharanian, H. (2003). The impact of institutional ownership on corporate operating performance. New York University Working Paper.

David, P., Hitt, M. A., \& Gimeno, J. (2001). The role of institutional investors in influencing R\&D. Academy of Management Journal, 44, 144-157. http://dx.doi.org/10.2307/3069342

Davis, G. F., \& Thompson, T. A. (1994). A social movement perspective on corporate control. Administrative Science Quarterly, 39, 141-173. http://dx.doi.org/10.2307/2393497

Del Guercio, D., \& Hawkins, J. (1999). The motivation and impact of pension fund activism. Journal of Financial Economics, 52, 293-340. http://dx.doi.org/10.1016/S0304-405X(99)00011-2

Demsetz, H., \& Lehn, K. (1983). The structure of ownership and the theory of the firm. Journal of Law and Economics, 26(2), 375-393. http://dx.doi.org/10.1086/467041

Demsetz, H., \& Lehn, K. (1985). The structure of Corporate Ownership: Causes and consequences. Journal of Political Economy, 93(6), 1155-1177. http://dx.doi.org/10.1086/261354

Dowen, R. J. (1995). Board director quality and firm performance. International Journal of the Economics of Business, 2, 123-132. http://dx.doi.org/10.1080/758521100

Eakins, S. (1995). An Empirical Investigation of Monitoring by Institutional Investors. American Business Review, 13, 67-85.

Eisenhardt, K. (1989). Agency theory: An assessment and review. Academy of Management Review, 14, 57-74. 
http://dx.doi.org/10.5465/AMR.1989.4279003

Fama, E. (1980). Agency problems and the theory of the firm. Journal of Political Economy, 88, 288-307. http://dx.doi.org/10.1086/260866

Fama, E., \& Jensen, M. (1983). Separation of ownership and control. Journal of Law and Economics, 26, 301-325. http://dx.doi.org/10.1086/467037

Gillan, S. L., \& Starks, L. T. (2003). Corporate Governance, Corporate Ownership, and the Role of Institutional Investors: A Global Perspective. Journal of Applied Finance, 13(2), 4-22. http://dx.doi.org/10.2139/ssrn.439500

Gilson, R. J., \& Kraakman, R. (1991). Reinventing the outside director: An agenda for institutional investors. Stanford Law Review, 43, 863-906. http://dx.doi.org/10.2307/1228922

Griffin, J. J., \& Mahon, J. F. (1997). The corporate social performance and corporate financial performance debate: Twenty-five years of incomparable results. Business \& Society, 36, 5-31. http://dx.doi.org/10.1177/000765039703600102

Hansen, G. S., \& Hill, C. W. (1991). Are institutional investors myopic? A time-series study of four technology driven industries. Strategic Management Journal, 1, 1-16. http://dx.doi.org/10.1002/smj.4250120102

Hartzel, J., \& Starks, L. (2003). Institutional investors and executive compensation. The Journal of Finance, 58 , 2351-2374. http://dx.doi.org/10.1108/03074351311283559

Hill, C. W., \& Snell, S. A. (1988). External Control, Corporate Strategy, and Firm Performance in $\begin{array}{llll}\text { Research-intensive Industries. Strategic Management Journal, 9, 577-590. } & \text {. }\end{array}$ http://dx.doi.org/10.1002/smj.4250090605

Holderness, C. G., \& Sheehan, D. P. (1988). The role of majority shareholders in publicly held corporations: An $\begin{array}{llll}\text { exploratory analysis. Journal of Financial Economics, 20, 317-346. } & \text {. }\end{array}$ http://dx.doi.org/10.1016/0304-405X(88)90049-9

Holderness, C. G., Kroszner, R. S., \& Sheehan, D. P. (1999). Were the good old days that good? Changes in managerial stock ownership since the Great Depression. Journal of Finance, 54, 435-469. http://dx.doi.org/10.1111/0022-1082.00114

Jacobs, M. T. (1991). Short-term America: The Causes and Cures of Our Business Myopia. Boston, MA: Harvard Business School Press.

Jennings, W. W. (2005). Further Evidence on Institutional Ownership and Corporate Value. Advances in Financial Economic, 11, 171-211. http://dx.doi.org/10.1016/S1569-3732(04)11008-6

Jensen, M. (1986). The agency cost of free cash flow. American Economic Review-Papers and Proceeding, 76, 326-329.

Jensen. M., \& Meckling, W. (1976). Theory of the firm: Managerial behavior, agency costs and ownership structure. Journal of Financial Economics, 3, 305-360. http://dx.doi.org/10.1016/0304-405X(76)90026-X

Johnson, R., \& Greening, D. (1999). The effects of corporate governance and institutional ownership on corporate social performance. Academy of Management Journal, 42, 564-580. http://dx.doi.org/10.1177/0149206305277797

Klein, A. (1998). Firm performance and Board Committee Structure. Journal of Law and Economics, 41, 137-165. http://dx.doi.org/10.1086/467391

La Porta, R., Lopez-de Silanes, F., Shleifer, A., \& Vishny, R. (1999). Legal Determinants of external Finance, Journal of Finance, 52(3), 1131-1150. http://dx.doi.org/10.1111/j.1540-6261.1997.tb02727.x

Lemmon, M. L., \& Lins, K. V. (2003). Ownership Structure, Corporate Governance and Firm Value: Evidence from the East Asian Financial Crisis. Journal of Finance, 58, 1445-1468. http://dx.doi.org/10.1111/1540-6261.00573

Lins, K. V. (2003). Equity ownership and firm value in emerging markets. Journal of Financial and Quantitative Analysis, 38, 159-184. http://dx.doi.org/10.2307/4126768

McConnell, J. L., \& Servaes, H. (1990). Additional evidence on equity ownership and corporate value. Journal of Financial Economics, 27, 595-612. http://dx.doi.org/10.1016/0304-405X(90)90069-C

Mehran, H. (1995). Executive compensation structure, ownership, and firm performance. Journal of Financial 
Economics, 38, 163-184. http://dx.doi.org/10.1016/0304-405X(94)00809-F

Mizruchi, M. S. (1983). Who controls whom? An examination of the relations between management and boards of directors in large American corporations. Academy of Management Review, 8, 426-435. http://dx.doi.org/10.5465/AMR.1983.4284426

Noe, T. (2002). Institutional activism and financial market structure. Review of Financial Studies, 15, 289-319. http://dx.doi.org/10.1093/rfs/15.1.289

Nor, F. M., \& Ariffin, B. (2005). Does pyramiding have an impact on firm's capital structure decision among Malaysian distress companies? Corporate Ownership \& Control, 2(4), 93-106.

Norburn, D., Boyd, B. K., Fox, M., \& Muth, M. (2000). International corporate governance reform. European Business Journal, 12(3), 116-133.

Porter, M. E. (1992). The competitive advantage of nations. London: Mcmillan.

Pound, J. (1992). Raiders, targets and politics: The history and future of American corporate control. Journal of Applied Corporate Finance, 5, 6-18. http://dx.doi.org/10.1111/j.1745-6622.1992.tb00222.x

Renneboog, L. (2000). Ownership, managerial control and the governance of companies listed on the Brussels Stock Exchange. Journal of Banking and Finance, 24, 1959-1995. http://dx.doi.org/10.1016/S0378-4266(99)00128-4

Ryan, L. V., \& Schneider, M. (2003). Institutional investor power and heterogeneity: Implications for agency and stakeholder theories. Business Society, 42, 398-429. http://dx.doi.org/10.1177/0007650303260450

Samad, F. A. (2004). Corporate governance and ownership structure in the Malaysian corporate sector. Advances in Financial Economics, 9, 355-385. v10.1016/S1569-3732(04)09014-0

Seifert, B., Gonenc, H., \& Wright, J. (2005). The international evidence on performance and equity ownership by insiders, blockholders and institutions. Journal of Multinational Financial Management, 15, 171-191. http://dx.doi.org/10.1016/j.mulfin.2004.08.003

Shleifer, A., \& Vishny, R. (1986). Large shareholders and corporate control. The Journal of Political Economy, 94, 461-488. http://dx.doi.org/10.1086/261385

Shleifer, A., \& Vishny, R. (1997). A survey of corporate governance. Journal of Finance, 52, 737-783. http://dx.doi.org/10.3386/w5554

Singh, J., \& Davidson III, W. N. (2003). Agency cost, ownership structure and corporate governance mechanism. Journal of Banking and Finance, 27(5), 793-816. http://dx.doi.org/10.1016/S0378-4266(01)00260-6

Smith, M. P. (1996). Shareholder activism by institutional investors: Evidence from CalPERS. Journal of Finance, 51, 227-252. http://dx.doi.org/10.1111/j.1540-6261.1996.tb05208.x

Starks, L. T. (1987). Performance incentive fees: An agency theoretic approach. Journal of Financial and Quantitative Analysis, 22, 33-50. http://dx.doi.org/10.2307/2330867

Stulz, R. (1990). Managerial discretion and Optimal Financing Policies. Journal of Financial Economics, 26, 3-27. http://dx.doi.org/10.1016/0304-405X(90)90011-N

Thomsen, S., \& Pedersen, T. (2000). Ownership structure and economic performance in the largest European $\begin{array}{lllll}\text { companies. Strategic } & \text { Management }\end{array}$ http://dx.doi.org/10.1002/(SICI)1097-0266(200006)21:6

Tihanyi, L., Johnson, R. A., Hoskisson, R. E., \& Hitt, M. A. (2003). Institutional ownership differences and international diversification: The effects of boards of directors and technological opportunity. Academy of Management Journal, 46(2), 195-211. http://dx.doi.org/10.2307/30040614

Tobin, J. (1969). A general equilibrium approach to monetary theory. Journal of Money Credit and Banking, 1, 15-29. http://dx.doi.org/10.2307/1991374

Tricker, B. (1998). The Role of the Institutional Investor in Corporate Governance. Corporate Governance: An International Review, 6(4), 213-216. http://dx.doi.org/10.1111/1467-8683.00109

Wahal, S. (1996). Pension fund activism and firm performance. Journal of Financial and Quantitative Analysis, 21, 1-23. http://dx.doi.org/10.2307/2331384

Wahal, S., \& McConnell, J. J. (2000). Do institutional investors exacerbate managerial myopia? Journal of Corporate Finance, 6, 307-329. http://dx.doi.org/10.1016/S0929-1199(00)00005-5 
Weir, C., \& McKnigh, P. (2002). Internal and external governance mechanisms: Their impact on the performance of large UK public companies. Journal of Business Finance and Accounting, 29, 579-611. http://dx.doi.org/10.1111/1468-5957.00444

Westphal, J. D., \& Zajac, E. J. (1998). The symbolic management of stockholders: Corporate governance reforms and shareholder reactions. Administrative Science Quarterly, 43, 127-153. http://dx.doi.org/10.2307/2393593

Zahra, S. A., \& Pearce, J. (1989). Boards of directors and corporate financial performance: A review and integrative model. Journal of Management, 15, 291-244. http://dx.doi.org/10.1177/014920638901500208

Zahra, S. A. (1996). Governance, ownership and corporate entrepreneurship: The moderating impact of industry technological opportunities. Academy of Management Journal, 39, 1713-1735. http://dx.doi.org/10.2307/257076

\section{Copyrights}

Copyright for this article is retained by the author(s), with first publication rights granted to the journal.

This is an open-access article distributed under the terms and conditions of the Creative Commons Attribution license (http://creativecommons.org/licenses/by/3.0/). 